DOI https://doi.org/10.18551/rjoas.2018-09.02

\title{
SOCIAL CONFLICT OF INDONESIAN BORDER COMMUNITIES AND THE DEMOCRATED REPUBLIC OF TIMOR LESTE: A CASE STUDY OF BOUNDARIES IN NORTH CENTRAL TIMOR AND OECUSSE DISTRICTS
}

\author{
Nino Handrianus* \\ Postgraduate Program, Faculty of Social and Political Sciences, \\ University of Brawijaya, Indonesia \\ Kanto Sanggar, Mu'adi Sholih \\ Faculty of Social and Political Sciences, University of Brawijaya, Indonesia \\ *E-mail: ninoandi88@gmail.com
}

\begin{abstract}
Border is the gateway of the state which at the same time becomes an international door between one country and another; therefore it is appropriate if the border region becomes the face of the country concerned. However, this has not yet been seen in the fact that the people in the North Central Timor Regency are directly adjacent to the Republic of Timor Leste's Democratic Republic, due to the fact that various social conflicts have taken place there. Therefore, this paper examines the dynamics of the conflict that occurred in the border region between Indonesia and the Democratic Republic of Timor Leste in relation to the boundary conflict between the two countries. Using the theory of social conflict put forward by Ralf Dahrendorf, researchers tried to explore the reality of social conflict in the border region, by using a case study approach and qualitative methods, it was concluded that the reality of existing social conflicts based on interviews found indications of structural conflict. and functional because of conflicts that occur because the government does not involve community elements in issuing policies so that the determination of boundaries is not in accordance with the expectations of the community, causing conflict between the two groups of people in the border area, namely the people in six villages in North Central Timor Regency community in Oecusse District.
\end{abstract}

\section{KEY WORDS}

Social Conflict, Structural Conflict, Functional Conflict

The Unitary State of the Republic of Indonesia is very famous for a thousand islands stretching along its sovereign territory consisting of 17,508 islands, both small islands and very long border perimeter with neighboring countries. One of the territories of the Republic of Indonesia which is in the form of land and directly adjacent to other countries is the North Central Timor Regency which is part of the province of East Nusa Tenggara.

East Timor before becoming a sovereign country, this region became part of one of the twenty-seven provinces in Indonesia and became part of Indonesia since 1975, under the control of President Suharto. But East Timor finally split and declared independence in 1999 through a poll conducted on 30 August 1999 under the supervision of the United Nations Mission in East Timor (UNAMET). After separating from the Republic of Indonesia the interim administration was run by the United Nations through the United Nations Transition in East Timor (UNTAET) until the transfer of sovereignty in 2002. After the transfer of full sovereignty by the United Nations Transition in East Timor (UNTAET) to the new government of East Timor on 20 May 2002 the people of East Timor hold a government as an independent State, the government of the Republic of Timor Leste Democratic Republic of Indonesia (RDTL) as the implementation of the people's mandate certainly seeks to maintain all territories both land, sea and air. One of the problems faced by RDTL is the issue of setting borders, especially the border on land with the Unitary Republic of Indonesia (NKRI). This is because the two countries' land borders consist of two parts, namely the border around Oecusse, 
which is an enclave that is part of Timor Leste's sovereignty in West Timor which is the territory of the Republic of Indonesia, and separated about $60 \mathrm{~km}$ from its parent region, both borders along $149.9 \mathrm{~km}$. which divides the island of Timor into West Timor and East Timor in the East, so that the determination of territorial boundaries is the main goal that must be resolved for good relations between the two countries of Indonesia and the Democratic Republic of Timor Leste.

A long history of conflict issues the boundary between the two countries of Indonesia and the Democratic Republic of East Timor can be grouped into five periods, there is a long period since the time of colonialism to the present. The grouping of the period can be described as follows. First: the period of Colonialism. This period began in 1701-1945 where at that time the Dutch colonized Indonesia and the Portuguese occupied East Timor. During this period there was a dynamic division of regions between the two nations, as a limit for natural resource management, so that the two countries agreed to carry out delimitation and demarcation, which was known as the A Convention for Demarcation of Portuguese and Dutch Dominions on the Island of Timor, which was signed On 1 October in the Netherlands, which did not go well, a second ensuing negotiation came to be known as the Permanent Court of Arbitration (PAC), which was made in 1914. This period ended with the independence of the Indonesian people in 1945, and the border region changed the name of the border between Indonesia and Portuguese Timor. Second: Post-Independence Indonesia. During this period Indonesia was independent and had the right to regulate and manage its entire territory, but at this time the East Timor Island was still under Portuguese Colonialism so that the area was known as Portuguese Timor. At that time an attempt was made to demarcate specifically in the Oecusse region carried out by Indonesia and Portuguese Timor. Third: Integration of East Timor. This period occurred in 1975-1999 where in this period the ownership of the area changed from Portuguese Colonial to Indonesian, starting with the Carnation Revolution by the Fretilin which caused the Portuguese to leave East Timor, followed by the integration of East Timor into a part of Indonesia as a province 27 th at that time. Then the existing territorial boundary has changed to the provincial boundary. At this time there was no conflict between communities because both Indonesia and East Timor were still part of Indonesia. During this period, efforts were also made by Indonesia to determine its territorial boundaries but were not recognized by the International Boundary or International Recognition. Fourth: Pre-independence, which began after the East Timor reverendum in 1999-2002. It was at this time that a new country was born, facilitated by the United Nations through UNAMET (United Nation Mission in East Timor), so that everything related to East Timor was represented by UNTAET, including bilateral relations with Indonesia to the establishment of national borders. During this time UNTAET and Indonesia formed a Joint Border Committee (JBC), to determine the border areas of the two countries. Fifth: Independence as a Sovereign State, starting from 2002 to the present. Confirmation of the territorial boundaries was again made by the two countries because UNTAET no longer had a role as a representative of the East Timorese government, because East Timor was officially independent as a sovereign country and changed its name to the Democratic Republic of East Timor. or the Indonesian Democratic Republic of Timor Leste. the efforts of both countries to determine the boundaries of the establishment of subcommittees that are at the technical level affirmation borders of the country called by the technical sub-committee of Border Demarcation Regulations or abbreviated TSC-BDR.

Up to this time the issue of social conflict borders between Indonesia and the Democratic Republic of Timor Leste, especially in the North Central Timor District with the Oecusse District there are six points, among them the First; Bijaelsunan / Oelnasi / Crus, part of Manusasi Village, West Miomaffo District, which has Unresolved segment status because the status of land in this area is still sterile and should not be controlled by both countries, both Indonesia and the Democratic Republic of East Timor. Second; Tubu Banat / Oben, located in Nilulat and Tubu Village, Bikomi Nilulat District. Third; Nefo Nunpo is located in Haumeniana Village, Bikomi Nilulat District. Fourth; Pistana is located in the village of Inbate and Nainaban, which is located in the Bikomi Nilulat District. Fifth ; Subina located in the village of Inbate and Nainaban. The boundary problem in the Bikomi Nilulat District is 
included in thecategory Unsuveyed segment because the Indonesian people in Bikomi Nilulat consider that this land is ulayat land, which is unilaterally taken by Timor Leste (Oecusse District), the area referred to is $\pm 14 \mathrm{Km}$ which, if the imposition of state borders is based on the 1904 treaty between Portuguese and Dutch colonials. The people claim this area because they have customary agreements that have occurred before the Dutch Colonial and Portuguese colonized the island of Timor. Social conflicts that occur in various border areas, including the sale of fuel oil, because the price offered in Oecusse is very high, and there are illegal border crossers, but the most prominent of all forms of social conflict is the establishment of boundaries between the two countries, which can affect other social problems.

Referring to the concept put forward by Ralf Dahrendrof that the reality of conflicts that occur in community groups is a common thing to happen in order to create life stability, and structural aspects in a society where each component is mutually influential, then the conflict or consensus according to Dahrendrof can be solved by rescue valves that can come from inside groups and also outside groups involved in the conflict. Rescue valves that are able to bridge the issue of border conflict, because they see the highest authority and power that exists in the community and the district government of North Central Timor because the community understands the problem of conflicts that occur in their own territory, without neglecting the participation of other parties to take part in the problem conflict between the two countries.

Based on the description above, the focus of this research is to look at the dynamics of the conflict of the Indonesian border community with the Republic of Timor Leste, the case study in North Central Timor District and Oecusse District.

\section{METHODS OF RESEARCH}

The research approach used is qualitative research, with case study methods. In addition to the case study method there are still other methods such as experiments, surveys, historical, and documentary information analysis but researchers are more interested in the case study method. The case study method was chosen because it was very helpful for researchers in analyzing the case to be studied because the case study method helps researchers in defining the case to be investigated, determining that the data collected is really relevant, and what should be done in relation to the collected data .

The focus of the research carried out in this paper is to look at the dynamics of social conflict, and the conflict process and see the role of traditional leaders, central and regional governments in overcoming social conflicts on the border of North Central Timor Regency, especially at several points of potential conflict, namely in Bijaelsunan, Tubu, Nefo Nunpo, Pistana, Subina, Bah Ob / Nelu, with the Democratic Republic of East Timor, especially the Oecusse District.

This research emphasizes how the process of social conflict occurs, then how to see the actors behind social conflict, and what solutions are offered to resolve border social conflicts. The research site is the place where the observation object of the research object will be examined by researchers. The site of this study is the six points of conflict in the North Central Timor Regency, namely: Bijaelsunan / Oelnasi located in Manusasi Village, West Miomafo District, North Central Timor Regency. Pistana is located in Sunkaen Village, Bikomi Nilulat District, North Central Timor Regency. Subina, located in Inbate Village, Bikomi Nilulat District, North Central Timor Regency. Nelu / Bah Obe located in Sunsea Village, Naibenu District, North Central Timor Regency.

The stages of the research are three stages: first stage: literature review of various types of research that have been carried out in the border areas mentioned above, both from individual researchers, students and survey institutions. the second stage: analyzing and identifying the components and aspects related to social conflict issues that are examined and integrated with the data obtained in the field. the third stage: describes the problems of social conflicts that occur and includes various kinds of new elements that have a reciprocal relationship with the reality of conflicts that occur in border communities. 


\section{RESULTS OF STUDY}

Dynamics Of Conflict In Indonesia And Timor Leste Borders. Conflicts that occurred on the border of North Central Timor District with Oecusse District were inter-community conflicts in both border regions between 2012-2013. The conflict that occurred in 2012, exactly on the $31 \mathrm{st}$, happened to strike each other between the people of Haumeniana Village and the Pasabbe community, which was triggered by the construction of Customs Service Offices, Immigration and Quarantine Offices (CQI), East Timor in the disputed neutral zone. All the trees in the area were cut down by the East Timorese side, and this action triggered a mutual attack between the two border communities, before finally being disbanded by the TNI and UPF (East Timor Border Security Forces).

After a year of running precisely in 2013 there was also a conflict between the two border communities, triggered by the construction of a new road carried out by the East Timorese, which according to the people of North Central Timor the road had crossed the NKRI as far as 500 meters and also passed the free zone as far as 50 meter. While based on an agreement between the two countries in 2005, the two countries did not have the rights to the designated free zone. In addition to building new roads, the East Timorese government also damaged border poles, damaged the gates of the Indonesian guard post and also damaged nine ancestral graves of the Nelu community in North Central Timor Regency.

The reality that occurred on the ground was that the East Timorese people built houses and settled in the disputed areas and this was the lack of good response from the Indonesian border community because the East Timorese were deemed not to have carried out the agreements that had been implemented in 2005, between the two countries may not use free zones.

Another problem that occurs is the closure of the traditional market (international market), by the TNI serving on the border precisely on 12 May 2018 because there are people who were arrested in Oecusse for entering Timor Leste through illegal channels, resulting in the economy in the border region become obstructed due to the incident. Based on the results of interviews with several community leaders in Haumeniana Village it is known that this kind of incident is not the first time it has happened but has repeatedly happened. Therefore, issues related to borders need to get important attention in establishing a brotherhood between communities in the border regions of both Indonesia and the Democratic Republic of Timor Leste.

The Role of Indigenous Families and Central and Regional Governments. There are two categories of boundary conflicts between Indonesia and the Democratic Republic of Timor Leste, namely unresolved segment and elemental segment. The area included in the unresolved segment in North Central Timor Regency is the Manusasi Village precisely in Bijaelsunan, East Miomaffo District. The status of the land is sterile and cannot be managed by both parties, both Indonesian and Timorese people, and this land has not been measured together. The community is still questioning the 489 land area, which is $2.7 \mathrm{~km}$ long, or an area of $142.7 \mathrm{Ha}$ in the area. The Indonesian side (Manusasi community) wants the national borders to start from Tugu Bijaelsunan, follow the ridge to Oben, while the East Timorese (Oecusse people), want the border to start from Tugu Bijaelsunan following the Miomaffo River Valley, to Oben (Kolne, 2017). This difference of opinion is based on the customary agreement that has taken place between the two parties in ancient times, so that until now the problem has not been resolved with certainty and clearness. Whereas the areas included in thecategory are the unsuveyed segmentSubina segment up to the Oben, which has an area of $\pm 14 \mathrm{Km}$, which is actually for the border communities of Indonesia, this land becomes the customary rights of the border community of North Central Timor Regency, Bikomi Nilulat District which includes 6 Villages namely: Inbate, Sunkaen, Nainaban, Haumeniana, Nilulat, and Tubu (Kolne, 2017). The people claimed that their territory was taken over by the government of Timor Leste, if they used the division of the border area based on the Dutch and Portuguese colonial treaties. So far the efforts that have been made between the government and the people of the two countries are by holding ameeting 
Technical Sub-Committeeon the Border Demarcation Regulation, which discusses technical matters related to border issues and the last agreement made in 2017 includes the following:

- Strengthening the rope brotherhood in order to preserve the values of customs that have been instilled by the ancestors in the philosophy of Ansaof Mese Atoni Pah Meto Nekaf Mese;

- Support the establishment of peace on the boundary as stipulated in the customary oath by the ancestors and expected by both countries;

- Establish cooperation in order to improve the dignity of the community in the social, cultural and economic fields;

- Recognize and strengthen the customary boundaries between the Kingdoms of Liurai Sila, Sonbai Sila, Beun Sila, and Afo Sila according to their oath;

- Inter-state boundary lines do not become a point of dispute as they have been so far, but rather become a social point and point of brotherhood;

- The results of the meeting need to be socialized to the entire community of both countries;

- Encouraging the governments of the two countries to facilitate a similar meeting in 2018 in Ambenu, technical matters related to the attendance of the participants so as not to be complicated.

The results of the study indicate that there are indications that the main cause of the conflict is the establishment of rules regarding the boundary between the two countries, namely Indonesia and the Democratic Republic of East Timor. Using Ralf Dahrendorf's conflict theory of conflict, some basic conclusions can be drawn, namely:

First, the conflict that occurred at the border of North Central Timor and Oecusse Districts is a functional structural coflict because the determination of policies related to borders is very detrimental to the local community. The government policy stipulates the division of national borders based on inheritance from Portuguese and Dutch colonials when colonizing the island of Timor.

Second, the people of North Central Timor Regency are guided by customary law (unwritten law) where an agreement has been made between the king of Miomaffo (one of the great kings in the District of Central Timor with King Amu who is from Oecusse, when the marriage occurred in \pm 1700 .

Third, coordination and discussion with border communities, especially those in North Central Timor District about the border to get the implication from the community before making a bilateral agreement between the two countries.

\section{CONCLUSION}

Based on the discussion on the border social conflict in North Central Timor District with Oecusse District, it can be concluded among others are:

Basis of the agreement used as the setting of the boundary between the two countries that used the 1904 treaty which was the result of inheritance from the Portuguese and Dutch colonial governments should again be reviewed, taking into account the customary agreements that have taken place between the two a community group around the border regions of the two countries.

The social conflict that occurred in North Central Timor and Oecusse Districts was a structural conflict, in which conflicts involving the communities of the two countries were due to legal products caused by the improperly targeted central government that caused prolonged conflict in the midst of at the border.

Conflict is also a functional conflict in which the conflict also occurs due to the dysfunction of the implementation of the duties and responsibilities of the central government and its coordination with the very weak regional government, so that there is the potential of throwing responsibilities from the regional government to the central government.

The existence of a very complicated bureaucracy causes overlapping responsibilities for managing border issues. 
Recommendations and proposals given by the regional government as an intermediary for the community to the central government have not been followed up firmly.

Weak central government attention to the management of conflict issues borders between the two countries, even though the border itself has a very large influence where the border region is an international entrance.

Based on the perspective of the cultural approach of the two communities which are on the border, the two countries have the same background of one descendant with the same cultural background and customs.

Monitoring, securing, controlling the parties who violate the results of the convention with neighboring countries.

Make important improvements to the relevant legal / bilateral products so that they do not have an impact on political, economic, cultural, and security issues.

\section{RECOMMENDATIONS}

Based on some of the conclusions above, there are some recommendations that need to get serious attention in solving the problems of social border conflicts between Indonesia, especially in North Central Timor District with the Democratic Republic of Timor Leste or Oecusse District, among them The following:

The Indonesian government in this case the central government needs to negotiate with the government of the Republic of East Timor in resolving the boundaries of the social conflict that occurred in 6 villages in the North Central Timor Regency, whose status is still in dispute.

A dialogue is needed to listen to the input and suggestions from the community at the village level, so that the resolution of social conflicts on the borders of the two countries is right on target, taking into account local wisdom or unwritten agreement that has occurred between border communities.

The need for the construction of facilities and infrastructure in the border region because the conditions in the border area in six villages in North Central Timor Regency are very alarming.

There needs to be budget support both from the central government and the regional government to develop the border area to become a state and international gateway.

There needs to be an improvement in the applicable legal products related to the establishment of boundaries so that there will no longer be victims of border communities between the two countries.

\section{REFERENCES}

1. Deeley, N. 2001. The International Boundaries of East Timor. Boundary and Territory Briefing.

2. Gumilar, Nugraha 2017. Military Campaign Support for Indonesian Diplomacy in the Land Borders of Indonesia - Timor Leste. University of Defense.

3. Kolne, Y. 2015. Implementation of the RI-RDTL Border Agreement in Efforts to Resolve Border Problems. Politika: Journal of Political Science 5 , 2-30.

4. Kolne, Y. 2017. Un-Resolved Border Conflict Resolution and Un-Surveyed Segment Through Cultural Approach. POLITIKA , 5.

5. Pamungkas, C. 2009. Border authorities, refugees, and illegal economic activities on the RI-Timor Leste border ", in Ganewati Wuryandari (Ed.). Security in the Indonesian East Timor Border: Reference Source and Management Policy. Yogyakarta: Student Library.

6. Ritzer, G. 2001. Social Book Hand Book. Jakarta: Nusa Media.

7. Septariani, M. 2014. Border Disputes in the Indonesian Land Area. Legal Journal , 1-8.

8. Susilo, E. 2010. The Dynamics of Social Structure in Coastal Ecosystems. UB Press.

9. Wuryandari, G. 2009. Security on the Indonesia-Timor Leste border: Source of threats and management policies. Yogyakarta: Student Library.

10. Yin, PD Robert. 2015. Case Studies (Design and Methods). Jakarta: Rajawali Press. 